\title{
REMOVAL KLORIDA, TDS DAN BESI PADA AIR PAYAU MELALUI PENUKAR ION DAN FILTRASI CAMPURAN ZEOLIT AKTIF DENGAN KARBON AKTIF
}

\author{
Oleh : Wahyu Nugroho *) dan Setyo Purwoto **)
}

\begin{abstract}
Abstrak
Salah satu sumber air yang masih banyak digunakan oleh masyarakat adalah air sumur gali, akan tetapi tidak semuanya memenuhi syarat kesehatan, terutama apabila air yang ada di sumur gali tersebut bersifat payau. Agar air payau dapat dimanfaatkan oleh masyarakat, maka perlu dilakukan pengolahan terlebih dahulu untuk menghilangkan kadar garamnya, salah satunya adalah dengan menggunakan media pengolahan karbon aktif, zeolit aktif dan resin penukar ion.

Penelitian bertujuan untuk membandingkan efisiensi penurunan kadar parameter uji, yaitu besi, klorida dan TDS pada air payau terhadap masing - masing varian reaktor, yaitu varian reaktor A (50\% zeolit aktif : $50 \%$ karbon aktif); varian reaktor B (25\% zeolit aktif : $75 \%$ karbon aktif); varian reaktor C (75\% zeolit aktif : $25 \%$ karbon aktif). Air payau akan masuk pada tabung filtrasi terlebih dahulu yang berisi media filter campuran antara zeolit aktif dan karbon aktif, selanjutnya mengalir ke tabung yang berisi resin penukar kation dan anion.

Penelitian ini menggunakan media zeolit aktif dan karbon aktif yang mempunyai ukuran \pm $6.3 \mathrm{~mm}$, resin penukar kation AMBERLITE ${ }^{\mathrm{TM}} \mathrm{IR} 120 \mathrm{Na}$ dan resin penukar anion AMBERLITE ${ }^{\mathrm{TM}}$ IRA402 Cl. Ketebalan media pengolahan sebesar $70 \mathrm{~cm}$ pada masing-masing tabung reactor, dengan tinggi tabung reaktor $100 \mathrm{~cm}$. Debit aliran ditentukan sebesar $0.3 \mathrm{~L} / \mathrm{menit}$.

Dari hasil penelitian diketahui bahwa variasi campuran C dengan komposisi $75 \%$ zeolit aktif : $25 \%$ karbon aktif mempunyai efisiensi penurunan yang paling tinggi diantara variasi lainnya,yaitu mampu menurunkan kadar besi sebesar $67 \%$, kadar klorida $65 \%$ dan kadar TDS $63 \%$. Semakin banyak jumlah zeolit pada campuran media antara zeolit aktif dan karbon aktif, maka mempunyai efisiensi penurunan yang semakin tinggi terhadap kadar parameter TDS, klorida dan besi.
\end{abstract}

Kata kunci : pengolahan air payau, zeolit aktif, karbon aktif dan penukar ion.

\section{PENDAHULUAN}

Salah satu sumber air yang masih banyak digunakan oleh masyarakat adalah air sumur gali, akan tetapi tidak semuanya memenuhi syarat kesehatan. Faktor-faktor yang dapat mempengaruhi rendahnya kualitas air sumur gali antara lain : musim, konstruksi, jenis dan kemiringan tanah, jarak dari sumber pengotoran dan perilaku makhluk hidup disekitarnya.

Bagi masyarakat yang tinggal didaerah pantai atau lokasi tanahnya yang mengandung mineral tinggi, sebagian besar air sumur gali di daerah tersebut termasuk jenis air payau. Air payau atau brackish Water adalah air yang mempunyai salinitas antara $0,5 \mathrm{ppt} \mathrm{s} / \mathrm{d} 17 \mathrm{ppt}$. Sebagai perbandingan, air tawar mempunyai salinitas kurang dari 0,5 ppt dan air minum maksimal 0,2 ppt. Air payau mengandung natrium dan klorida relatif tinggi serta $\mathrm{Ca}$ dan $\mathrm{Mg}$ yang menyebabkan kesadahan.
Air payau merupakan salah satu sumber air yang tidak dapat dimanfaatkan oleh manusia secara langsung untuk keperluan sehari-hari, maka dari itu perlu dilakukan pengolahan-pengolahan terlebih dahulu untuk mengurangi jumlah mineral atau kadar garamnya

Pengolahan air menggunakan filtrasi dan penukar ion merupakan teknologi yang mudah diterapkan dan lebih ekonomis dibandingkan dengan teknologi penyulingan. Media filtrasi yang sering digunakan untuk mengolah air payau adalah membran, zeolit aktif, arang aktif, pasir dan lain-lain. Penukar ion banyak didapatkan di tempat umum dengan berbagai macam produk, baik untuk penukar ion negatif (anion exchange) maupun penukar ion positif (cation exchange)

\footnotetext{
*) Mahasiswa Teknik Lingkungan

${ }^{* *}$ Dosen Teknik Lingkungan

Universitas PGRI Adi Buana Surabaya
} 


\section{Batasan dan Ruang Lingkup Penelitian}

\section{Batasan Penelitian}

a) Penelitian ini menggunakan proses penukar ion (ion exchanger) dan filtrasi campuran antara zeolit aktif dengan karbon aktif.

b) Menggunakan tiga tabung reaktor dengan rincian tabung reaktor pertama diisi campuran zeolit aktif dan karbon aktif, tabung reaktor kedua diisi penukar kation dan tabung reaktor ketiga diisi anion.

c) Zeolit aktif dicampur dengan karbon aktif dalam satu tabung reaktor dengan komposisi yang bervariasi, dengan ketentuan :

Variasi A (50\% zeolit aktif : $50 \%$ karbon aktif)

Variasi B (25\% zeolit aktif : $75 \%$ karbon aktif)

Variasi C $(75 \%$ zeolit aktif : $25 \%$ karbon aktif)

d) Resin penukar ion pada semua variasi kondisinya sama dan tidak ada perbedaan.

e) Kecepatan alir pada masing - masing variasi adalah sama, yaitu $0,3 \mathrm{~L} /$ menit.

f) Tinggi kolom media pengolahan sama semua, yaitu $70 \mathrm{~cm}$.

g) Paramater uji yang digunakan untuk mengetahui efektivitas proses adalah parameter uji klorida, besi dan total padatan terlarut ( TDS ).

h) Untuk mengetahui hasil yang representatif, maka dilakukan pengambilan sampel air hasil pengolahan sebanyak 3 ( tiga ) kali untuk masing masing variasi setelah debit aliran stabil, dengan jedah waktu antar pengambilan selama 30 menit.

\section{Ruang lingkup penelitian}

Penelitian filtrasi ini diterapkan di laboratorium workshop-rekayasa lingkungan UNIPA Surabaya dan dianalisis oleh laboratorium uji kualitas lingkungan BLH Prop Jatim. Contoh uji diambil dari air sumur di daerah Wonorejo Indah Timur VII/10 Kecamatan Rungkut dengan sifat fisik berbau, berwarna, payau.

\section{Perumusan Masalah}

1. Berapa persen penurunan kadar klorida ( $\mathrm{Cl}^{-}$) dalam air, dari pengolahan yang dilakukan pada tiga macam variasi campuran zeolit aktif dan karbon aktif.

2. Berapa persen penurunan kadar besi ( $\mathrm{Fe}$ ) dalam air, dari pengolahan yang dilakukan pada tiga macam variasi campuran zeolit aktif dan karbon aktif.

3. Berapa persen penurunan kadar TDS dalam air, dari pengolahan yang dilakukan pada tiga macam variasi campuran zeolit aktif dan karbon aktif.

4. Komposisi campuran (zeolit aktif dengan karbon aktif) mana yang mampu menurunkan kadar parameter uji paling tinggi diantara ketiga variasi yang dilakukan.

5. Apakah air hasil pengolahan sudah memenuhi baku mutu air bersih sesuai dengan Peraturan Menteri Kesehatan No. 416 tahun 1990.

\section{Tujuan Penelitian}

1) Untuk mengetahui berapa persen penurunan kadar klorida $\left(\mathrm{Cl}^{-}\right)$dalam air dari pengolahan yang dilakukan pada tiga macam variasi campuran zeolit aktif dan karbon aktif.

2) Untuk mengetahui berapa persen penurunan kadar besi ( $\mathrm{Fe}$ ) dalam air dari pengolahan yang dilakukan pada tiga macam variasi campuran zeolit aktif dan karbon aktif.

3) Untuk mengetahui berapa persen penurunan kadar TDS dalam air dari pengolahan yang dilakukan pada tiga macam variasi campuran zeolit aktif dan karbon aktif.

4) Untuk mengetahui komposisi campuran yang paling efektif antara zeolit teraktifasi dengan karbon aktif dalam menurunkan kadar parameter uji.

5) Untuk mengetahui apakah air hasil pengolahan sudah memenuhi baku mutu air bersih sesuai dengan Peraturan Menteri Kesehatan No. 416 tahun 1990.

\section{Manfaat Penelitian}

1. Mendapatkan suatu teknologi alternatif yang sederhana dan mudah dalam pengoperasiaannya sehingga dapat menurunkan kadar garam atau mineral pada air.

2. Memberikan data informasi tentang teknologi pengolahan yang dilakukan pada penelitian ini untuk menurunkan kadar garam atau mineral dalam air dengan 
menggunakan proses pertukaran ion yang dipadukan dengan filtrasi (menggunakan media campuran antara zeolit aktif dan karbon aktif).

4. memperoleh data yang lebih lengkap tentang kemampuan teknologi yang digunakan pada penelitian ini.

\section{KAJIAN PUSTAKA}

\section{$\underline{\text { Air Bersih }}$}

Air bersih adalah salah satu jenis sumber daya berbasis air yang bermutu baik dan biasa dimanfaatkan oleh manusia untuk dikonsumsi atau dalam melakukan aktivitas mereka sehari - hari termasuk diantaranya sanitasi. Macam - macam sumber air bersih diantaranya :

\section{Air laut}

Air laut mempunyai sifat asin karena mengandung garam $\mathrm{NaCl} 3 \%$.

\section{Air Atmosfer}

Air atmosfer jatuh ke bumi dalam bentuk air hujan. Air hujan mengandung banyak kotoran. Selain itu air hujan mempunyai sifat agresif terutama terhadap pipa-pipa penyalur maupun bak-bak reservoir, sehingga hal ini akan mempercepat terjadinya korosi atau karatan. Air hujan mempunyai sifat sadah, sehingga akan boros terhadap pemakaian sabun.

\section{Air Permukaan}

Air permukaan berasal dari aliran langsung air hujan di permukaan bumi.

\section{Air tanah}

Air tanah adalah air yang berada di bawah permukaan tanah di dalam zona jenuh dimana tekanan hidrostatiknya sama atau lebih besar dari tekanan atmosfer. Air tanah terbagi atas air tanah dangkal dan air tanah dalam. Air tanah dangkal, terjadi karena adanya daya proses peresapan air dari permukaan tanah. Air dangkal ini ditinjau dari segi kualitas baik, segi kuantitas kurang dan tergantung pada musim. Air tanah dalam, terdapat setelah lapis rapat air yang pertama. Pengambilan air tanah dalam,
3. Sebagai bahan kajian dan referensi kepada penelitian berikutnya untuk dapat mengembangkan hasil yang diperoleh dari penelitian ini dan mencoba berbagai variasi percobaan sehingga nantinya akan tak semudah pada air tanah dangkal karena harus digunakan bor dan memasukkan pipa kedalamannya sehingga dalam suatu kedalaman biasanya antara 100-300 $\mathrm{m}^{2}$.

\section{Mata air}

Mata air yaitu air tanah yang keluar dengan sendirinya ke permukaan tanah dalam hampir tidak terpengaruh oleh musim dan kualitas atau kuantitasnya sama dengan air dalam.

Air merupakan zat pelarut yang penting untuk makhluk hidup dan bagian terpenting dalam proses metabolisme. Air juga dibutuhkan dalam fotosintesis dan respirasi. Tubuh manusia terdiri dari 55\% sampai $78 \%$ air, tergantung dari ukuran badan. Agar dapat berfungsi dengan baik, tubuh manusia membutuhkan antara satu sampai tujuh liter air setiap hari untuk menghindari dehidrasi; jumlah pastinya bergantung pada tingkat aktivitas, suhu, kelembaban, dan beberapa faktor lainnya. Syarat kesehatan kualitas air didasarkan pada peraturan menteri kesehatan RI No 416 tahun 1990 tentang persyaratan kualitas air bersih.

\section{Pengolahan Air}

Proses pengolahan air dapat dilakukan dengan berbagai cara, tergantung pada rencana dan tujuan penggunaan air itu sendiri. Ada beberapa istilah dalam sistem pengolahan air , misalnya ;

\section{Pelunakan ( softening).}

Istilah ini digunakan dalam proses untuk menyingkirkan atau mengurangi kesadahan air.

\section{Pemurnian ( purification).}

Istilah ini berbeda dari pelunakan, yaitu menyingkirkan atau menghilangkan bahan-bahan organik dan mikro organisme dari air. 


\section{Demineralisasi.}

Istilah ini digunakan dalam proses untuk mengurangi atau menghilangkan semua kandungan mineral - mineral yang ada di dalam air.

Demineraslisasi sering digunakan dalam proses pengolahan air di berbagai industri atau sektor pelayanan publik dengan cara atau teknik yang berbeda - beda. Pada umumnya demineralisasi di pabrik digunakan untuk pengolahan air umpan boiler, air backwash, bahan baku penolong pada industri minuman atau makanan, dan lain - lain.

a) Distilasi (penyulingan) adalah proses pemisahan komponen dari suatu campuran yang berupa larutan cair-cair dimana karakteristik dari campuran tersebut adalah bercampur homogen dan mudah menguap, selain itu komponenkomponen tersebut mempunyai perbedaan tekanan uap dan hasil dari pemisahannya menjadi komponenkomponennya atau kelompok - kelompok komponen.

b) Adsorpsi atau penyerapan adalah proses pemisahan bahan dari campuran gas atau cair. Bahan yang akan dipisahkan ditarik oleh permukaan zat padat yang menyerap (adsorben).

c) Proses penghilangan ion-ion atau mineral yang terlarut dalam air dapat menggunakan penukar ion (ion exchanger).

\section{Resin Sintesis Penukar lon}

Pada mulanya resin penukar ion yang digunakan adalah dari material alami, namun dengan semakin majunya teknologi dan ilmu pengetahuan, saat ini telah digunakan resin penukar ion sintetik yang di buat dari kapolimerisasi zat - zat tertentu yang mengandung ion pelarutan sebagai gugus fungsinya.

Pertukaran ion berlangsung dengan cara difusi fluida yang keluar masuk resin, sehingga ion-ion yang lebih besar dari ukuran tertentu tidak dapat bereaksi karena seleksi tertentu dari derajat ikatan silang resin. Gugus fungsi berupa asam atau basa yang diikat oleh polimer pembentuk resin dan menentukan sifat dasar dari resin yang dibentuk. Jumlah gugus fungsi persatuan berat resin menentukan kapsitas jasal atau kapasitas paritik pertukaran yang dinyatakan sebagai dry weight capasity (meq/g resin).
Faktor lain yang mempengaruhi sifat resin adalah jenis gugus fungsi, yang menentukan jenis tipe resin penukar ion yang dibentuk dan di luar pengaruh terhadap kesetimbangan pertukaran dan selektivitas.

Berdasarkan muatan ion yang dapat dipertukarkan, resin pertukaran ion dapat dikelompokkan menjadi :

a) Resin pertukaran kation

1) Resin penukar kation asam kuat.

Resin ini mengandung gugus fungsional yang diturunkan dari asam kuat yang beroperasi dengan siklus $\mathrm{H}$ ( hidrogen ) seperti asam sulfat. Regenerasi dilakukan dengan menggunakan larutan $\mathrm{HCl}$ atau $\mathrm{H}_{2} \mathrm{SO}_{4}$. Efisiensi dari regenerasi resin ini antara $30 \%$ sampai $40 \%$.

2) Resin penukar kation asam lemah. Resin ini mengandung gugus fungsional yang diturunkan dari asam lemah yang beroperasi dengan siklus karboksilat ( $\mathrm{R}-\mathrm{COOH}$ ) seperti fenolat atau asam karboksilat. Resin ini hanya dapat memisahkan garam dari asam kuat dan basa kuat saja. Efisiensi dari regenerasi resin ini mendekati 100\%.

b) Resin pertukaran anion ( mengandung anion yang dapat dipertukarkan ). Resin ini dibagi menjadi 2 jenis, yaitu :

1) Resin penukar anion basa kuat.

Resin ini mengandung gugus fungsional yang berasal dari gugus ammonium kuartener tipe I dan tipe II

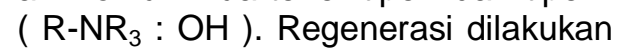
dengan menggunakan larutan $\mathrm{NaOH}$ atau $\mathrm{NH}_{4} \mathrm{OH}$. Efisiensi dari regenerasi resin ini antara $30 \%$ sampai $50 \%$.

2) Resin penukar kation asam lemah.

Resin ini mengandung amina primer, sekunder dan atau tersier sebagai gugus fungsional ( $\mathrm{R}-\mathrm{NH}_{2}$ ). Resin ini hanya dapat memisahkan asam kuat, tetapi tidak bisa memisahkan asam lemah. Efisiensi dari regenerasi resin ini mendekati $100 \%$.

Proses pertukaran ion melibatkan reaksi kimia antara ion dalam fasa cair dengan ion dalam fasa padat. Ion-ion tertentu dalam larutan lebih mudah terserap oleh solid penukar ion, dan karena elektronetralitas harus dijaga, solid penukar melepas ion dan dipertukarkan ion dalam larutan. Dalam proses demineralisasi, maka sebagai contoh ; kation $\mathrm{Na}^{+}$dan anion $\mathrm{Cl}^{-}$ disisihkan dari air dan solid resin melepas ion $\mathrm{H}^{+}$untuk ditukar dengan ion $\mathrm{Na}^{+}$, serta $\mathrm{OH}^{-}$ditukar dengan $\mathrm{Cl}^{-}$dari air sehingga 
kandungan $\mathrm{Na}^{+}$dan $\mathrm{Cl}^{-}$dalam air menjadi berkurang atau hilang.

Operasi sistem pertrukaran ion dilakukan dalam empat tahap, yaitu :

a) Tahap Layanan

Tahap layanan adalah tahap dimana terjadi reaksi pertukaran ion. Sifat dari tahap ini ditentukan oleh kosentrasi ion yang dihilangkan terhadap waktu atau volume air produk yang dihasilkan. Hal yang perlu diperhatikan pada tahap layanan ini adalah kapasitas bahan pertukaran ion (lon exchange load). Tahap layanan ini dilakukan dengan cara mengalirkan air dari atas (down flow).

b) Tahap Pencucian balik

Tahap ini dilakukan jika kemampuan resin telah mencapai titik jenuh dan kotor. Pencucian balik dilakukan dengan mengalirkan air produk dari bawah ke atas (up flow). Pencucian balik mempunyai sasaran sebagai berikut :

1) Pemecahan resin yang menggumpal.

2) Penghilangan partikel halus yang terperangkap dalam ruang resin.

3) Penghilangan kantong - kantong gas yang terdapat dalam reaktor.

4) Pembentukan ulang lapisan resin bed dengan pengembangan bed antara $50 \%$.

c) Tahap Regenerasi

Tahap regenerasi adalah operasi penggantian ion yang telah jenuh dengan ion awal yang semula berada dalam matriks resin dan pengembalian kapasitas ke tingkat yang diinginkan. Larutan regenerasi harus dapat menghasilkan titik puncak dari ion yang digantikan. Larutan regenerasi untuk kation menggunakan $\mathrm{HCl}$ atau $\mathrm{H}_{2} \mathrm{SO}_{4}$, sedangkan untuk anion menggunakan larutan $\mathrm{NaOH}$. Operasi regenerasi dilakukan dengan mengalirkan larutan regenerasi dari atas. Beberapa hal yang perlu diperhatikan dalam proses regenerasi antara lain :

1) Kosentrasi larutan harus selalu konstan.
2) waktu pengaliran larutan regenerasi harus tepat.

d) Tahap Pembilasan

Tahap pembilasan dilakukan untuk menghilangkan sisa larutan regenerasi yang terperangkap oleh resin. Pembilasan dilakukan menggunakan air produk dengan aliran down flow dan dilakukan dalam dua tingkat, yaitu :

1) Tingkat laju alir rendah untuk menghilangkan larutan regenerasi.

2) Tingkat laju alir tinggi untuk menghilangkan sisa ion.

\section{Zeolit}

Zeolit merupakan suatu mineral yang dihasilkan dari proses hidrothermal pada batuan beku basa. Mineral ini biasanya ditemukan dalam celah - celah ataupun rekahan batuan. Selain itu zeolit juga merupakan endapan dari aktifitas vulkanik yang banyak mengandung silica. Adanya zeolit dialam berkontribusi dalam pembersihan lingkungan khususnya dalam mereduksi pencemaran air. Karena sifat yang dimiliki oleh zeolit, maka mineral ini dapat dimanfaatkan dalam berbagai bidang, secara umum zeolit mampu menyerap, menukar ion dan menjadi katalis.

Sifat zeolit sebagai adsorben dan penyaring molekul, dimungkinkan karena struktur zeolit yang berongga, sehingga zeolit mampu menyerap sejumlah besar molekul yang berukuran lebih kecil atau sesuai dengan ukuran rongganya. Selain itu kristal zeolit yang telah terdehidrasi merupakan adsorben yang selektif dan mempunyai efektivitas adsorpsi yang tinggi. Adsorpsi terjadi pada permukaan pori membran. Partikel zeolit memiliki tiga tipe pori, yaitu macropore dan micropore (masing-masing dengan ukuran $>50 \mathrm{~nm}$ dan $<2 \mathrm{~nm})$. Di antara keduanya terdapat mesopore. Macropore merupakan jalan masuk ke dalam partikel menuju micropore. Macropore tidak berkontribusi terhadap besarnya luas permukaan membran zeolit. Sebaliknya, micropore adalah penyebab besarnya luas permukaan membran zeolit. Micropore tersebut sebagian besar 
terbentuk selama proses aktifasi. Pada micropore inilah sebagian besar peristiwa adsorpsi terjadi.

Sedangkan sifat zeolit sebagai penukar ion karena adanya kation logam alkali dan alkali tanah. Kation tersebut dapat bergerak bebas di dalam rongga dan dapat dipertukarkan dengan kation logam lain dengan jumlah yang sama. Akibat struktur zeolit berongga, anion atau molekul berukuran lebih kecil atau sama dengan rongga dapat masuk dan terjebak.

Pengolahan zeolit secara garis besar dapat dibagi dalam dua tahap, yaitu preparasi dan aktivasi :

\section{1) Tahapan preparasi}

zeolit diperlakukan sedemikian rupa agar mendapatkan zeolit yang siap olah. Tahap ini berupa pengecilan ukuran dan pengayakan. Tahapan ini dapat menggunakan mesin secara keseluruhan atau dengan cara sedikit konvensional.

2) Tahapan aktivasi Aktivasi zeolit dapat dilakukan dengan cara pemanasan atau penambahan pereaksi kimia baik asam maupun basa:

(a) Aktivasi pemanasan, dilakukan zeolit dalam pengering putar menggunakan bahan umpan yang mempunyai kadar air sekitar $40 \%$, dengan suhu tetap $230{ }^{\circ} \mathrm{C}$ dan waktu pemanasan selama tiga jam.

(b) Penambahan pereaksi kimia, dilakukan di dalam bak pengaktifan dengan $\mathrm{NaOH}$ dan $\mathrm{H} 2 \mathrm{SO} 4$, dimaksudkan untuk memperoleh temperatur yang dibutuhkan dalam aktivasi. Zeolit yang telah diaktivasi perlu dikeringkan terlebih dahulu, pengeringan ini dapat dilakukan dengan cara menjemurnya di bawah sinar matahari.

\section{Karbon Aktif}

Karbon berpori atau lebih dikenal dengan nama karbon aktif, digunakan sebagai adsorben untuk menghilangkan warna, pengolahan limbah, pemurnian air. Karbon aktif adalah arang yang telah mengalami perubahan sifat-sifat fisika dan kimianya karena dilakukan perlakuan aktifisasi dengan aktifator bahan bahan kimia ataupun dengan pemanasan pada temperatur tinggi. Karbon aktif akan membentuk amorf yang sebagian besar terdiri dari karbon bebas dan memiliki permukaan dalam yang berongga, warna hitam, tidak berbau, tidak berasa, dan mempunyai daya serap yang jauh lebih besar dibandingkan dengan karbon yang belum menjalani proses aktivasi.

Secara umum, aktivasi adalah mengubah karbon dengan daya serap rendah menjadi karbon yang mempunyai daya serap tinggi. Untuk menaikan luas permukaan dan memperoleh karbon yang berpori, karbon diaktivasi, misalnya dengan menggunakan uap panas, gas karbondioksida dengan temperatur antara $700-1100^{\circ} \mathrm{C}$, atau penambahan bahanbahan mineral sebagai aktivator. Selain itu aktivasi juga berfungsi untuk mengusir tar yang melekat pada permukaan dan pori-pori karbon. Aktivasi menaikan luas permukaan dalam ( internal area ), menghasilkan volume yang besar, berasal dari kapiler kepiler yang sangat kecil, dan mengubah permukaan dalam dari struktur pori. Menghasilkan volume yang besar, berasal dari kapiler-kapiler yang sangat kecil, dan mengubah permukaan dalam dari struktur pori.

\section{Klorida}

Klorida adalah ion yang terbentuk dari unsur klor yang mendapatkan satu elektron untuk membentuk suatu anion atau ion yang bermuatan negative $\left(\mathrm{Cl}^{-}\right)$. Kata klorida dapat pula diartikan sebagai senyawa kimia dimana satu atau lebih atom klornya memiliki ikatan kovalen dalam molekul. Tingkat toksisitas klorida tergantung pada gugus senyawanya, misalnya Natrium Klorida (NaCl) sangat tidak beracun, tetapi karbonil khlorida sangat beracun. Di Indonesia, Khlor digunakan sebagai desinfektan dalam penyediaan air minum. Dalam jumlah banyak, klorida akan menimbulkan rasa asin, korosi pada pipa sistem penyediaan air panas. Sebagai desinfektan, residu khlor di dalam penyediaan air sengaja dipelihara, tetapi khlor ini dapat terikat pada senyawa organic dan membentuk halogen-hidrokarbon (CL$\mathrm{HC)}$ banyak diantaranya dikenal sebagai senyawa-senyawa karsinogenik.

Beberapa dampak yang ditimbulkan oleh klorida pada lingkungan adalah menimbulkan pengkaratan atau dekomposisi pada logam karena sifatnya yang korosif, ikan dan biota air tidak bisa bertahan hidup dalam kadar klorida yang tinggi serta 
kerusakan ekosistem pada perairan terbuka atau eutrofikasi.

\begin{tabular}{llll}
\multicolumn{2}{c}{ Metode yang } & digunakan & dalam \\
penentuan & kadar & klorida & adalah \\
argentometri & (Mohr) & dengan & prinsip
\end{tabular} argentometri (Mohr) dengan prinsip
pengujiannya Senyawa klorida dalam contoh uji air dapat dititrasi dengan larutan perak nitrat dalam suasana netral atau sedikit basa ( $\mathrm{pH} 7$ sampai dengan $\mathrm{pH} 10$ ), menggunakan larutan indikator kalium kromat. Perak klorida diendapkan secara kuantitatif sebelum terjadinya titik akhir titrasi, yang ditandai dengan mulai terbentuknya endapan perak kromat yang berwarna merah kecoklatan.

\section{TDS ( Total Dissolved Solid)}

Salah satu faktor yang sangat penting dan menentukan bahwa air yang layak konsumsi adalah kandungan TDS (Total Dissolved Solid) atau total kandungan unsur mineral dalam air. Contoh unsur mineral dalam air adalah zat kapur, besi, timah, magnesium, tembaga, sodium, klorida, klorin dan lain-lain. Air yang mengandung TDS tinggi, sangat tidak baik untuk kesehatan manusia. Mineral dalam air tidak hilang dengan cara direbus.

Bila terlalu banyak mineral nonorganic di dalam tubuh dan tidak dikeluarkan, maka seiring berjalannya waktu akan mengendap di dalam tubuh yang berakibat tersumbatnya bagian tubuh. Misalnya bila mengendap di mata akan mengakibatkan katarak, bila di ginjal akan mengakibatkan batu ginjal atau batu empedu, di pembuluh darah akan mengakibatkan pengerasan pembuluh darah , tekanan darah tinggi, stroke, dan lain lain.

Ada dua metode yang dapat digunakan untuk mengukur kadar TDS dalam larutan, yaitu secara gravimetrik dan electrical conductivity (ukuran kemampuan suatu bahan untuk mengahantarkan arus listrik). Prinsip penentuan TDS secara gravimetrik adalah sampel disaring dengan kertas saring yang mempunyai pori maksimum $2 \mu \mathrm{m}$, kemudian filtrat diambil dengan volume tertentu dan ditempatkan pada cawan, lalu dikeringkan di oven, setelah itu baru ditimbang beratnya dan dihitung untuk mendapatkan nilai kadarnya. Sedangkan prinsip electrical conductivity adalah alat dicelupkan ke dalam larutan dan secara otomatis akan keluar hasil kadarnya.

\section{Besi}

Besi adalah logam dalam kelompok makromineral di dalam kerak bumi, tetapi termasuk dalam kelompok mikro dalam sistem biologi. Pada umumnya besi yang ada di dalam air dapat bersifat terlarut sebagai $\mathrm{Fe}^{2+}$ atau $\mathrm{Fe}^{3+}$. Dalam keadaan tereduksi ion besi di dalam air berada dalam bentuk fero ( ion besi dengan valensi II ). Apabila terdapat bahan oksidator atau karena pengaruh oksigen dari udara maka bentuk fero ini cepat teroksidasi menjadi ion feri (ion besi dengan valensi III) dan dapat bereaksi lagi menjadi oksida yang tidak larut. Dalam keadaan asam, dimana $\mathrm{pH}$-nya kurang dari 3,5 maka ion feri akan melarut. Bahan - bahan suspensi seperti limpur tanah liat dapat mengandung besi yang akan melarut dalam asam. Besi dalam air dapat menyebabkan noda - noda pada pakaian, porselin dan sebagainya.

Berdasarkan persyaratan kualitas air minum yang dibuat oleh Permenkes No.416/MENKES/PER/IX/199, kadar besi maksimum yang diperbolehkan sebesar 1,0 $\mathrm{mg} / \mathrm{L}$. Besi dapat larut pada $\mathrm{pH}$ rendah dan dapat menyebabkan air yang berwarna kekuningan, menimbulkan noda pada pakaian dan tempat berkembang biaknya bakteri creonothrinx, oleh sebab itu kadar besi tidak boleh lebih dari $1 \mathrm{mg} / \mathrm{L}$, karena dapat mempercepat pertumbuhan bakteri tersebut dan dapat menimbulkan rasa serta bau (Sutapa, 2000).

Salah satu metode untuk pengujian logam besi yang tepat adalah dengan menggunakan metode spektrofotometer serapan atom. Metode Atomic Absorbtion Spectrophotometre (AAS) atau Spektrofotometer Serapan Atom berprinsip pada absorbs cahaya oleh atom. Atom-atom menyerap cahaya tersebut pada panjang gelombang tertentu, tergantung pada sifat unsurnya. Dengan absorbsi energi, berarti memperoleh banyak energi suatu atom pada keadaan dasar dinaikan tingkat energinya ketingkat eksitasi. Keberhasilan analisis ini tergantung pada proses eksitasi dan memperoleh garis resonansi yang tepat (Puspita, 2007).

\section{METODE PENELITIAN}

Dalam penelitian ini, percobaan yang dilakukan bertujuan untuk memperoleh penemuan - penemuan yang berkenaan dengan aplikasi / penerapan teori-teori yang 
sudah dipaparkan. Sehingga penelitian ini dapat disebut sebagai penelitian eksperimen yaitu kesengajaan mengadakan manipulasi sesuatu variabel atau kondisi dengan langkah-langkah dan desain penelitian, mulai dari persiapan reaktor, persiapan media, persiapan dan pengambilan sampel, melakukan treatment hingga pengujian terhadap parameter yang sudah ditentukan dan pengolahan data yang dihasilkan. Adapun skema rancangan penelitian seperti pada gambar 1 berikut :

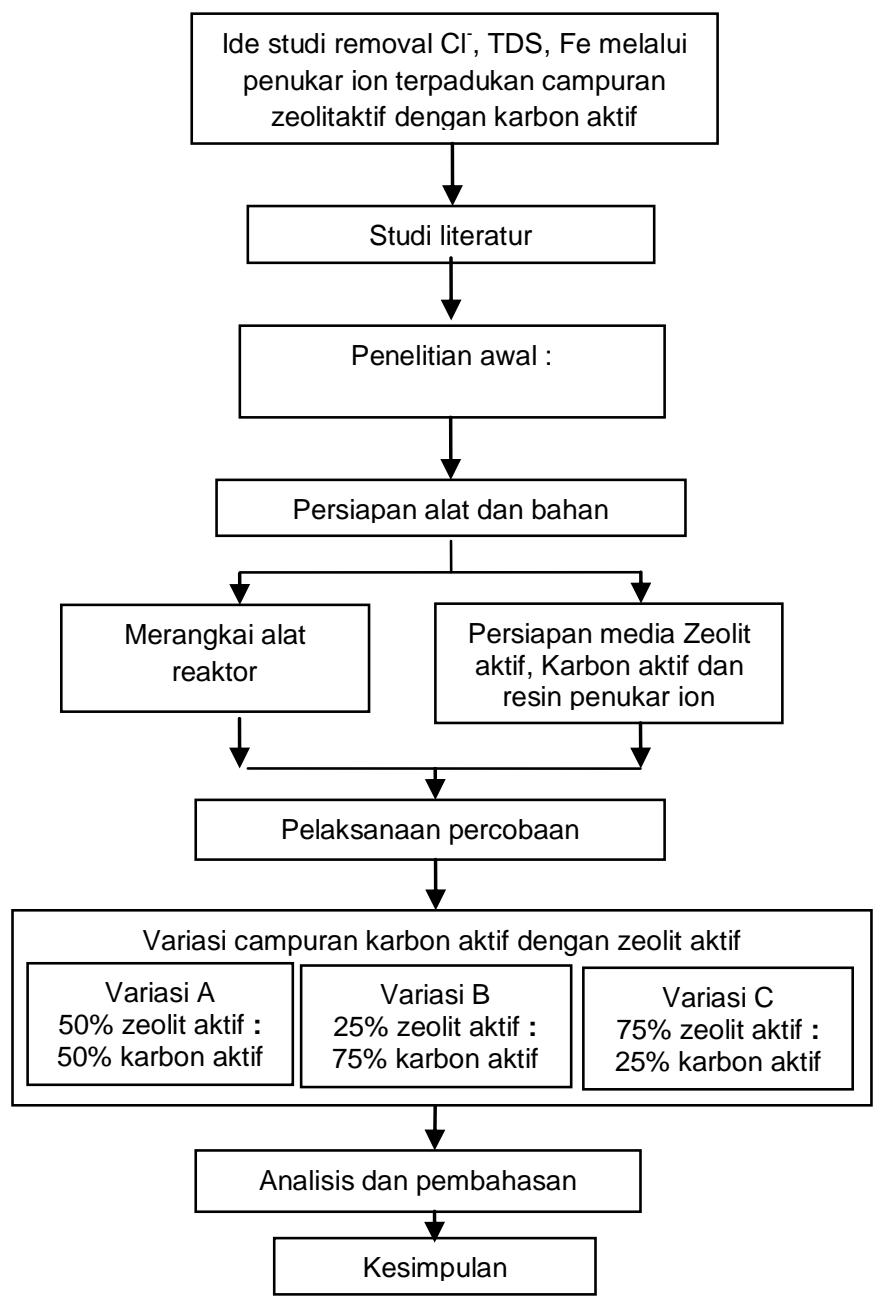

Gambar 1. Rancangan Penelitian

\section{Sample penelitian}

Sample penelitian yang digunakan adalah air sumur di Wonorejo Indah Timur VII/10 Kecamatan Rungkut Kota Surabaya dengan sifat fisik berbau, berwarna, dan payau, yang kemudian air tersebut dilakukan pengolahan atau treatment untuk penelitian di Laboratorium Teknik Lingkungan Universitas Adi Buana Surabaya Kampus
Menanggal. Air hasil olahan dianalisa di Laboratorium Uji Kualitas Lingkungan BLH Prov. Jatim di Jl. Wisata Menanggal 38 Surabaya.

\section{Metode Pengumpulan Data}

Metode pengumpulan data dilakukan dengan cara metode eksperimen membandingkan kinerja pengolahan air yang menggunakan media campuran zeolit aktif dan karbon aktif terpadukan resin penukar ion, dimana komposisi campuran zeolit aktif dan karbon aktif bervariasi. Indikator yang digunakan untuk mengetahui kinerja sistem pengolahan tersebut adalah efisiensi penurunan kadar klorida, besi dan TDS. Filtrasi menggunakan pipa PVC dengan diameter 4 inchi dengan tinggi kolom media $70 \mathrm{~cm}$. Pengambilan sampel air hasil olahan dilakukan sebanyak 3 (tiga) kali setelah debit stabil, dengan jedah waktu pengambilan selama 30 menit .

\section{Metode Analisis Data}

Data yang diperoleh ini merupakan data mentah sehingga harus diolah sesuai dengan tujuan penelitian yang telah dirumuskan untuk mendapatkan kesimpulan. Adapun metode yang digunakan dalam analisis data adalah dalam bentuk grafik dan tabel, kemudian selanjutnya dilakukan pembahasan dengan jalan membandingkan antar variasi.

\section{PENYAJIAN DAN ANALISIS DATA Penyajian data}

Data yang dihasilkan diperoleh dari hasil penelitian dilapangan secara langsung. Penelitian ini dilakukan di Laboratorium lingkungan UNIPA Surabaya dan dianalisis oleh laboratorium uji kualitas lingkungan BLH Prop jatim. Data yang sudah berhasil dikumpulkan melalui kegiatan penelitian ini adalah :

1. Data hasil uji untuk parameter klorida, TDS dan besi pada variasi A, yaitu komposisi campuran filter dengan perbandingan 50\% zeolit aktif : $50 \%$ karbon aktif. Pengambilan sampel dilakukan sebanyak tiga kali pada saat percobaan atau treatment dengan debit aliran $0.3 \mathrm{~L} /$ menit. 
tabel 1. data hasil analisis reaktor variasi $\mathrm{A}$

\begin{tabular}{|c|l|c|c|c|}
\hline \multirow{2}{*}{$\begin{array}{c}\mathrm{N} \\
\mathrm{O}\end{array}$} & ID sampel & \multicolumn{3}{|c|}{ PARAMETER UJI } \\
\cline { 3 - 5 } & $\begin{array}{l}\text { Klorida } \\
(\mathrm{mg} / \mathrm{L})\end{array}$ & $\begin{array}{c}\text { TDS } \\
(\mathrm{mg} / \mathrm{L})\end{array}$ & $\begin{array}{c}\text { Besi } \\
(\mathrm{mg} / \mathrm{L})\end{array}$ \\
\hline $\begin{array}{l}\text { 1 } \\
\text { n 1 }\end{array}$ & $\begin{array}{l}\text { Percobaa } \\
\mathrm{n} 2\end{array}$ & 370.2 & 735 & 0.92 \\
3 & $\begin{array}{l}\text { Percobaa } \\
\mathrm{n} 3\end{array}$ & 350.4 & 718 & 0.87 \\
\hline \multicolumn{2}{|c|}{ Rata - rata } & 361.27 & 726 & 0.83 \\
\hline 4 & Air baku & 934.4 & 1835 & 2.3 \\
\hline
\end{tabular}

2. Data hasil uji untuk parameter klorida, TDS dan besi pada variasi $\mathbf{B}$, yaitu komposisi campuran filter dengan perbandingan $25 \%$ zeolit aktif : $75 \%$ karbon aktif. Pengambilan sampel dilakukan sebanyak tiga kali pada saat percobaan atau treatment dengan debit aliran $0.3 \mathrm{~L} /$ menit

tabel 2. data hasil analisis reaktor variasi B

\begin{tabular}{|c|c|c|c|c|}
\hline \multirow{2}{*}{$\begin{array}{l}\mathrm{N} \\
\mathrm{O}\end{array}$} & \multirow{2}{*}{ ID sampel } & \multicolumn{3}{|c|}{ PARAMETER UJI } \\
\hline & & $\begin{array}{l}\text { Klorida } \\
\text { (mg/L) }\end{array}$ & $\begin{array}{c}\text { TDS } \\
\text { (mg/L) }\end{array}$ & $\begin{array}{c}\text { Besi } \\
\text { (mg/L) }\end{array}$ \\
\hline 1 & $\begin{array}{l}\text { Percobaa } \\
\text { n } 1\end{array}$ & 407.2 & 835 & 1.08 \\
\hline 2 & $\begin{array}{l}\text { Percobaa } \\
\text { n } 2\end{array}$ & 405.1 & 818 & 1.02 \\
\hline 3 & $\begin{array}{l}\text { Percobaa } \\
\text { n } 3\end{array}$ & 390.2 & 825 & 0.98 \\
\hline \multicolumn{2}{|c|}{ Rata - rata } & 400.83 & 826 & 1.03 \\
\hline 4 & air baku & 934.4 & 1835 & 2.3 \\
\hline
\end{tabular}

3. Data hasil uji untuk parameter klorida, TDS dan besi pada variasi C, yaitu komposisi campuran filter dengan perbandingan $75 \%$ zeolit aktif : $25 \%$ karbon aktif. Pengambilan sampel dilakukan sebanyak tiga kali pada saat percobaan atau treatment dengan debit aliran $0.3 \mathrm{~L} /$ menit tabel 3. data hasil analisis reaktor variasi $\mathrm{C}$

\begin{tabular}{|c|l|c|c|c|}
\hline \multirow{2}{*}{ NO } & \multirow{2}{*}{ ID sampel } & \multicolumn{3}{|c|}{ PARAMETER UJI } \\
\cline { 3 - 5 } & $\begin{array}{c}\text { Klorida } \\
(\mathrm{mg} / \mathrm{L})\end{array}$ & $\begin{array}{c}\text { TDS } \\
(\mathrm{mg} / \mathrm{L})\end{array}$ & $\begin{array}{c}\text { Besi } \\
(\mathrm{mg} / \mathrm{L})\end{array}$ \\
\hline 1 & Percobaan 1 & 337.2 & 685 & 0.81 \\
2 & Percobaan 2 & 325.1 & 668 & 0.73 \\
3 & Percobaan 3 & 320.8 & 672 & 0.77 \\
\hline \multicolumn{2}{|c|}{ Rata - rata } & 327.70 & 675 & 0.77 \\
\hline 4 & air baku & 934.4 & 1835 & 2.3 \\
\hline
\end{tabular}

\section{$\underline{\text { Analisis data }}$}

Metode yang digunakan dalam analisis data ini yaitu analisis secara tabel dan grafik kemudian dijelaskan dengan jalan membandingkan antar variasi. Data yang diperoleh merupakan data dari hasil pengujian yang dilakukan sendiri di UPT laboratorium Uji Kualitas Lingkuhan BLH Provinsi Jawa Timur.

\section{Efisiensi Penurunan Klorida}

Dari data yang dihasilkan pada masing-masing variasi campuran, khususnya untuk kadar klorida mengalami penurunan kosentrasi jika dibandingkan dari kadar klorida pada air baku yang belum diolah dengan kadar klorida pada air hasil olahan pada masing-masing variasi. Namun variasi mana yang mampu menurunkan kadar klorida dengan efisiensi tinggi, maka perlu kita kaji dengan menggunakan table dan grafik sebagai berikut:

$\underline{\text { tabel 4. data penurunan parameter klorida }}$

\begin{tabular}{|c|c|c|c|c|c|c|}
\hline \multirow[b]{2}{*}{$\begin{array}{l}\text { Percob } \\
\text { aan Ke }\end{array}$} & \multicolumn{2}{|c|}{ VARIASI A } & \multicolumn{2}{|c|}{ VARIASI B } & \multicolumn{2}{|c|}{ VARIASI C } \\
\hline & $\begin{array}{l}\mathrm{Cl}^{-} \\
(\mathrm{mg} / \\
\mathrm{L})\end{array}$ & $\begin{array}{c}\text { Efisie } \\
\text { nsi } \\
(\%)\end{array}$ & $\begin{array}{c}\mathrm{Cl}^{-} \\
(\mathrm{mg} / \\
\mathrm{L})\end{array}$ & $\begin{array}{c}\text { Efisie } \\
\text { nsi } \\
(\%)\end{array}$ & $\begin{array}{c}\mathrm{Cl}^{-} \\
(\mathrm{mg} / \mathrm{L}\end{array}$ & $\begin{array}{l}\text { Efisise } \\
\text { nsi (\%) }\end{array}$ \\
\hline 1 & $\begin{array}{c}370 . \\
2\end{array}$ & 60.38 & $\begin{array}{c}407 . \\
2\end{array}$ & 56.42 & $\begin{array}{c}337 . \\
2\end{array}$ & 63.91 \\
\hline 2 & $\begin{array}{c}350 . \\
4\end{array}$ & 62.50 & $\begin{array}{c}405 . \\
1\end{array}$ & 56.65 & $\begin{array}{c}325 . \\
1\end{array}$ & 65.21 \\
\hline 3 & $\begin{array}{c}363 . \\
2\end{array}$ & 61.13 & $\begin{array}{c}390 . \\
2\end{array}$ & 58.24 & $\begin{array}{c}320 . \\
8\end{array}$ & 65.67 \\
\hline $\begin{array}{c}\text { Rata- } \\
\text { rata }\end{array}$ & $\begin{array}{c}361 . \\
3\end{array}$ & 61.34 & $\begin{array}{c}400 . \\
8\end{array}$ & 57.10 & $\begin{array}{c}327 . \\
7\end{array}$ & 64.93 \\
\hline
\end{tabular}


Berdasarkan tabel 4 (Data Penurunan Parameter Klorida) di atas, menunjukkan bahwa penurunan kadar klorida paling tinggi dihasilkan dari pengolahan dengan tipe variasi C $(75 \%$ zeolit aktif : $25 \%$ karbon aktif) yang mampu menurunkan kadar klorida sebesar $64.93 \%$, sedangkan penurunan kadar klorida paling rendah dihasilkan dari pengolahan tipe variasi B (25\% zeolit aktif : $75 \%$ karbon aktif) yang mampu menurunkan kadar klorida sebesar $61.34 \%$. Berikut ini adalah grafik batang yang menunjukkan perbandingan efisiensi penurunan kadar klorida pada setiap variasi :

\section{grafik 1.grafik efisiensi penurunan kadar klorida}

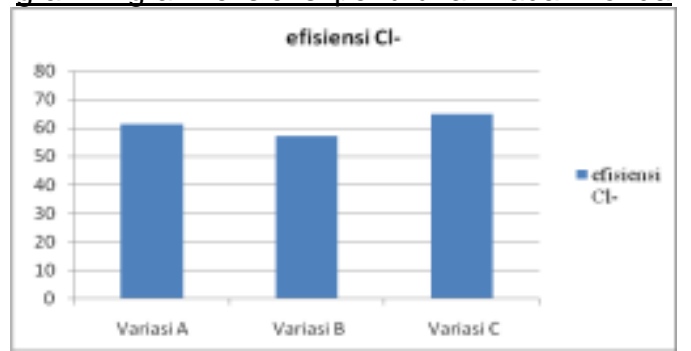

\section{Efisiensi Penurunan TDS}

Dari data yang dihasilkan pada masing-masing variasi campuran, khususnya untuk kadar TDS mengalami penurunan kosentrasi jika dibandingkan dari kadar TDS pada air baku yang belum diolah dengan kadar TDS pada air hasil olahan pada masing-masing variasi. Namun variasi mana yang mampu menurunkan kadar TDS dengan efisiensi tinggi, maka perlu kita kaji dengan menggunakan table dan grafik sebagai berikut:

\section{tabel 5. data penurunan parameter TDS}

\begin{tabular}{|c|c|c|c|c|c|c|}
\hline $\begin{array}{c}\text { Perco } \\
\text { baan } \\
\mathrm{Ke}\end{array}$ & \multicolumn{2}{|c|}{ VARIASI A } & \multicolumn{2}{c|}{ VARIASI B } & \multicolumn{2}{c|}{ VARIASI C } \\
\cline { 2 - 7 } & $\begin{array}{c}\text { TDS/ } \\
\mathrm{L})\end{array}$ & $\begin{array}{c}\text { Efisis } \\
\text { ensi } \\
(\%)\end{array}$ & $\begin{array}{c}\text { TDS } \\
(\mathrm{mg} / \\
\mathrm{L})\end{array}$ & $\begin{array}{c}\text { Efisis } \\
\text { ensi } \\
(\%)\end{array}$ & $\begin{array}{c}\text { TDS } \\
(\mathrm{mg} / \\
\mathrm{L})\end{array}$ & $\begin{array}{c}\text { Efisis } \\
\text { ensi } \\
(\%)\end{array}$ \\
\hline 1 & 735 & 59.95 & 835 & 54.50 & 685 & 62.67 \\
2 & 718 & 60.87 & 818 & 55.42 & 668 & 63.60 \\
3 & 725 & 60.49 & 825 & 55.04 & 672 & 63.38 \\
$\begin{array}{c}\text { Rata - } \\
\text { rata }\end{array}$ & $\begin{array}{c}726 . \\
0\end{array}$ & 60.44 & $\begin{array}{c}826 . \\
0\end{array}$ & 54.99 & 675. & 0 \\
\hline
\end{tabular}

Berdasarkan tabel 5 (Data
Penurunan Parameter TDS) diatas, menunjukkan bahwa penurunan kadar TDS paling tinggi dihasilkan dari pengolahan dengan tipe variasi C ( $75 \%$ zeolit aktif : $25 \%$ karbon aktif) yang mampu menurunkan kadar TDS sebesar $63.22 \%$, sedangkan penurunan kadar TDS paling rendah dihasilkan dari pengolahan tipe variasi $B$ (25\% zeolit aktif : $75 \%$ karbon aktif) yang mampu menurunkan kadar TDS sebesar $60.44 \%$. Berikut ini adalah grafik batang yang menunjukkan perbandingan efisiensi penurunan kadar TDS pada setiap variasi :

\section{grafik 2.grafik efisiensi penurunan kadar tds}

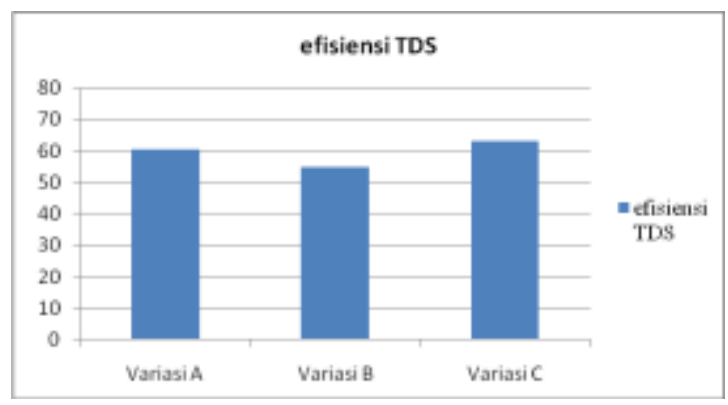

\section{Efisiensi Penurunan Besi}

Dari data yang dihasilkan pada masing-masing variasi campuran, khususnya untuk kadar besi mengalami penurunan kosentrasi jika dibandingkan dari kadar besi pada air baku yang belum diolah dengan kadar besi pada air hasil olahan pada masing-masing variasi. Namun variasi mana yang mampu menurunkan kadar besi dengan efisiensi tinggi, maka perlu kita kaji dengan menggunakan table dan grafik sebagai berikut:

\section{tabel 6. data penurunan parameter besi}

\begin{tabular}{|c|c|c|c|c|c|c|}
\hline \multirow{2}{*}{$\begin{array}{l}\text { Percob } \\
\text { aan Ke }\end{array}$} & \multicolumn{2}{|c|}{ VARIASI A } & \multicolumn{2}{|c|}{ VARIASI B } & \multicolumn{2}{|c|}{ VARIASI C } \\
\hline & $\begin{array}{c}\text { Besi } \\
(\mathrm{mg} / \mathrm{L})\end{array}$ & $\begin{array}{l}\text { Efisise } \\
\text { nsi (\%) }\end{array}$ & $\begin{array}{c}\text { Besi } \\
\text { (mg/L) }\end{array}$ & $\begin{array}{l}\text { Efisise } \\
\text { nsi (\%) }\end{array}$ & $\begin{array}{c}\text { Besi } \\
\text { (mg/L) }\end{array}$ & $\begin{array}{l}\text { Efisise } \\
\text { nsi (\%) }\end{array}$ \\
\hline 1 & 0.92 & 60.00 & 1.08 & 3.04 & 0.81 & 64.78 \\
\hline 2 & 0.87 & 62.17 & 1.02 & 55.65 & 0.73 & 68.26 \\
\hline 3 & 0.83 & 63.91 & 0.98 & 57.39 & 0.77 & 66.52 \\
\hline $\begin{array}{l}\text { Rata - } \\
\text { rata }\end{array}$ & 0.87 & 62.03 & 1.03 & 55.36 & 0.77 & 66.52 \\
\hline \multicolumn{7}{|c|}{ Berdasarkan tabel } \\
\hline $\begin{array}{l}\text { Penur } \\
\text { menu } \\
\text { paling } \\
\text { denga } \\
\text { karbo } \\
\text { kadar }\end{array}$ & $\begin{array}{l}\text { unan } \\
\text { jukka } \\
\text { ting } \\
\text { tipe } \\
\text { ak } \\
\text { besi }\end{array}$ & $\begin{array}{l}\text { Par } \\
\text { bah } \\
\text { dih } \\
\text { rarias } \\
\text { ya } \\
\text { sebe }\end{array}$ & $\begin{array}{r}\text { pete } \\
\text { pe } \\
\text { Ikar } \\
\text { m }\end{array}$ & $\begin{array}{l}\mathrm{Be} \\
\text { urunal } \\
\text { dari } \\
6 \text { zeol } \\
\text { npu } \\
52 \% \text {, }\end{array}$ & $\begin{array}{l}\text { nenu } \\
\text { sed }\end{array}$ & $\begin{array}{l}\text { diatas, } \\
\text { r besi } \\
\text { lahan } \\
\text { : } 25 \% \\
\text { unkan } \\
\text { ngkan }\end{array}$ \\
\hline pe & Ian & kada & bes & $\mathrm{pe}$ & $\mathrm{ig}$ & endah \\
\hline
\end{tabular}


dihasilkan dari pengolahan tipe variasi $\mathrm{B}$ (25\% zeolit aktif : $75 \%$ karbon aktif) yang mampu menurunkan kadar besi sebesar $62.03 \%$. Berikut ini adalah grafik batang yang menunjukkan perbandingan efisiensi penurunan kadar besi pada setiap variasi :

grafik 3.grafik efisiensi penurunan kadar Besi

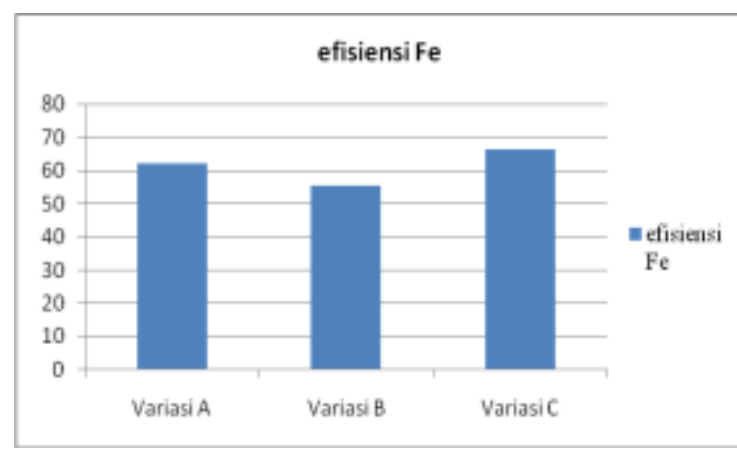

4. Efisiensi Penurunan Parameter Uji pada Masing-Masing Variasi

Untuk mengetahui variasi mana yang mampu menurunkan kadar parameter uji dengan efisiensi tinggi, maka kita menggunakan data gabungan dari beberapa data diatas. Secara garis besar data gabungan berisi tentang rerata efisiensi parameter uji pada masing-masing variasi. berikut ini adalah tabel efisiensi penurunan parameter uji :

tabel 7. data penurunan parameter uii

\begin{tabular}{|c|c|c|c|c|c|c|}
\hline \multirow{3}{*}{$\begin{array}{c}\text { Jenis } \\
\text { Varia } \\
\text { si }\end{array}$} & \multicolumn{6}{|c|}{ Parameter Uji } \\
\hline & \multicolumn{2}{|c|}{ Klorida } & \multicolumn{2}{|c|}{ TDS } & \multicolumn{2}{|c|}{ Besi } \\
\hline & $\begin{array}{c}\text { Kadar } \\
\text { (mg/L } \\
\text { ) }\end{array}$ & $\begin{array}{c}\text { Efisie } \\
\text { nsi } \\
(\%)\end{array}$ & $\begin{array}{c}\text { Kadar } \\
\text { (mg/L } \\
\text { ) }\end{array}$ & $\begin{array}{c}\text { Efisie } \\
\text { nsi } \\
(\%)\end{array}$ & $\begin{array}{c}\text { Kadar } \\
\text { (mg/L } \\
\text { ) }\end{array}$ & $\begin{array}{c}\text { Efisie } \\
\text { nsi } \\
(\%)\end{array}$ \\
\hline $\begin{array}{l}\text { Varia } \\
\text { si A }\end{array}$ & $\begin{array}{c}361.2 \\
7\end{array}$ & 61.34 & 726 & 60.44 & 0.87 & 62.03 \\
\hline $\begin{array}{l}\text { Varia } \\
\text { si B }\end{array}$ & $\begin{array}{c}400.8 \\
3\end{array}$ & 57.10 & 826 & 54.99 & 1.03 & 55.36 \\
\hline $\begin{array}{l}\text { Varia } \\
\text { si C }\end{array}$ & $\begin{array}{c}327.7 \\
0\end{array}$ & 64.93 & 675 & 63.22 & 0.77 & 66.52 \\
\hline
\end{tabular}

Berdasarkan tabel 7 (Data

Penurunan Parameter uji) diatas bahwa Variasi A mampu menurunkan kadar klorida sebesar $61.34 \%$, kadar TDS sebsear $60.44 \%$, kadar besi sebesar $62.03 \%$; sedangkan Variasi B mampu menurunkan kadar klorida sebesar $57.1 \%$, kadar TDS sebsear 54.99\%, kadar besi sebesar $55.36 \%$; dan Variasi C mampu menurunkan kadar klorida sebesar $61.34 \%$, kadar TDS sebsear $60.44 \%$, kadar besi sebesar $62.03 \%$. Dari data tersebut menunjukkan bahwa variasi yang mampu menurunkan kadar parameter uji dengan efisiensi yang tinggi adalah variasi C $(75 \%$ zeolit aktif : $25 \%$ karbon aktif), sedangkan efisiensi penurunan parameter uji yang paling rendah dihasilkan dari variasi B (25\% zeolit aktif : $75 \%$ karbon aktif).

Berikut ini adalah grafik efisiensi penurunan parameter uji pada setiap variasi pengolahan :

\section{grafik 7.grafik efisiensi penurunan parameter uji}

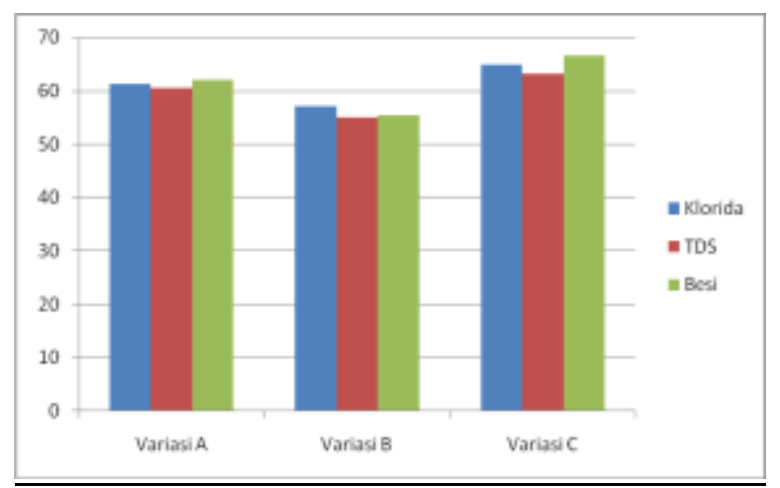

\section{Interpretasi Data}

Dari data hasil penelitian yang tersaji di atas, dapat diinterpretasikan bahwa variasi $\mathrm{C}$ dengan komposisi $75 \%$ zeolit aktif : 25\% karbon aktif, mempunyai efisiensi penurunan yang paling tinngi terhadap paramater uji dibandingkan dengan dua variasi lainnya, yaitu mampu menurunkan kadar klorida sebesar 64,93\%, kadar TDS sebesar 63,22\% dan kadar besi sebesar $66,52 \%$. Sedangkan variasi yang mampu menurunkan kadar parameter uji terendah dibandingkan variasi lainnya adalah variasi B dengan komposisi 25\% zeolit aktif : $75 \%$ karbon aktif, yaitu mampu menurunkan kadar klorida sebesar 57,1\%, kadar TDS sebesar 54,99\% dan kadar besi sebesar $55,36 \%$. Hal ini menunjukkan bahwa jumlah komposisi zeolit aktif berbanding lurus dengan efisiensi penurunan kadar paramater uji, dengan kata lain semakin banyak komposisi zeolit dalam variasi campuran, maka kemampuan menurunkan kadar parameter uji semakin besar.

Zeolit mempunyai sifat sebagai penukar ion karena adanya kation logam 
alkali dan alkali tanah. Kation tersebut dapat bergerak bebas didalam rongga dan dapat dipertukarkan dengan kation logam lain dengan jumlah yang sama. Akibat struktur zeolit berongga, anion atau molekul berukuran lebih kecil atau sama dengan rongga dapat masuk dan terjebak. Sedangkan karbon mempunyai sifat sebagai adsorben yang dapat mengadsorpsi gas dan senyawa-senyawa kimia tertentu atau sifat adsorpsinya selektif, tergantung pada besar atau volume pori-pori dan luas permukaan. Hal yang tidak kalah penting dalam menurunkan kadar parameter uji pada penenlitian ini adalah resin penukar ion. proses pertukaran ion melibatkan reaksi kimia antara ion dalam fasa cair dengan ion dalam fasa padat. Ion-ion tertentu dalam larutan lebih mudah terserap oleh solid penukar ion, dan karena elektronetralitas harus dijaga, solid penukar melepas ion dan dipertukarkan ion dalam larutan.

\section{SIMPULAN}

1. Kadar klorida mengalami penurunan dengan efisiensi yang bervariasi sebagai berikut :

a. Variasi A (50\% zeolit aktif : 50\% karbon aktif) mampu menurunkan kadar klorida dengan efisiensi $61 \%$.

b. Variasi B $(25 \%$ zeolit aktif : $75 \%$ karbon aktif) mampu menurunkan kadar klorida dengan efisiensi $57 \%$.

c. Variasi C $(75 \%$ zeolit aktif : $25 \%$ karbon aktif) mampu menurunkan kadar klorida dengan efisiensi $65 \%$.

2. Kadar TDS mengalami penurunan dengan efisiensi yang bervariasi sebagai berikut :

a. Variasi A $(50 \%$ zeolit aktif : $50 \%$ karbon aktif) mampu menurunkan kadar TDS dengan efisiensi $60 \%$.

b. Variasi B $(25 \%$ zeolit aktif : $75 \%$ karbon aktif) mampu menurunkan kadar TDS dengan efisiensi 55\%. c. Variasi C (75\% zeolit aktif : $25 \%$ karbon aktif) mampu menurunkan kadar TDS dengan efisiensi $63 \%$.

3. Kadar besi mengalami penurunan dengan efisiensi yang bervariasi sebagai berikut :

a. Variasi A (50\% zeolit aktif : $50 \%$ karbon aktif) mampu menurunkan kadar besi dengan efisiensi $62 \%$.

b. Variasi B (25\% zeolit aktif : $75 \%$ karbon aktif) mampu menurunkan kadar besi dengan efisiensi 55\%.

c. Variasi C (75\% zeolit aktif : $25 \%$ karbon aktif) mampu menurunkan kadar besi dengan efisiensi $67 \%$.

4. Campuran variasi C $(75 \%$ zeolit aktif : $25 \%$ karbon aktif) adalah komposisi campuran yang mempunyai efisiensi tertinggi diantara variasi campuran yang dilakukan dalam penelitian ini untuk menurunkan kadar parameter uji .

5. Baku mutu air bersih berdasarkan Peraturan menteri Kesehatan No. 416 tahun 1990 untuk parameter klorida sebesar $600 \mathrm{mg} / \mathrm{L}$, TDS $1000 \mathrm{mg} / \mathrm{L}$ dan besi $1 \mathrm{mg} / \mathrm{L}$. Jadi kualitas air hasil olahan yang dapat memenuhi baku mutu air bersih adalah dari reaktor variasi $\mathrm{C}$ dan reaktor variasi $A$, sedangkan air dari reaktor variasi $B$ tidak memenuhi baku mutu untuk parameter besi.

\section{DAFTAR PUSTAKA}

Anonymous,2009.SistemPengolahanAir.http://ladawanpiazza.blogspot.com/2009/04/sistempengolahan-air.html ( 24 Januari 2010 ).

Anonymous. Karbon aktif. http://id.wikipedia.org/wiki/karbon aktif ( 27 Januari 2010 )

Anonymous. Slow Sand Filter. http://en.wikipedia.org/wiki/slow sand filtration.

( 07 februari 2010 )

Anonymous. Activted carbon. http://en.wikipedia.org/wiki/activated carbon.

(27 Januari 2010)

Arfandy, Munsir, Teknik Penyediaan Air Bersih untuk Daerah Pedesaan "Skala Prioritas Pemilihan Sumber Air", Makalah dalam Proceeding Kursus Penyediaan Air di Pedesaan, Bandung, 1983. 
Atastina S.B, Praswasti P.D.K. Wulan, dan Syarifudin, 2005. Penghilangan Kesadahan Air Yang Mengandung lon $\mathrm{Ca}^{2+}$ Dengan Menggunakan Zeolit Alam Lampung Sebagai

Penukar, JURNAL PENELITIAN Fakultas Teknik - UI, depok .hal 1-5

Bapedalda Propinsi Jatim, 2007. Pedoman Pemantauan Kualitas Air Sungai Di Jawa Timur. Surabaya

Bell, R. G., 2001, What are zeolites? URL: http://www.bza.org/zeolites.html. (27 Januari 2010 )

Collins, M. R. 1998. "Assessing Slow Sand Filtration and Proven Modifications." In Small Systems Water Treatment Technologies: State of the Art Workshop. NEWWA Joint Regional Operations Conference and Exhibition. Marlborough, Massachusetts.

Gede H Cahyono, 2009. Adsorpsi Karbon Aktif http://gedehace.blogspot.com/2009/03/adsorpsi-karbon-aktif.html (27 januari 2010 ).

Hassler, John W.1974. Activated Carbon. Chemical Publishing Co., Inc., NY.

Sutrisno, Joko, 2006. Buku Ajar Satuan Operasi. UNIPA. Surabaya

Nusa Idaman said, 1996. Teknologi Pengolahan Air Bersih Dengan Proses Saringan Pair Lambat "Upflow", http://www.kelair.bppt.go.id/Sitpa/Artikel/Pasir/pasir.html _ ( 07 Februari 2010).

Peraturan menteri kesehatan RI No 416 tahun 1990 tentang persyaratan kualitas airbersih.

Robert C. Rice, 1974. Journal (Water Pollution Control Federation), Vol. 46, No. 4, http://www.jstor.org/pss/25038184. (10 juli2010).

Reynold, 1982. the ecology of freshwater phytoplankton.

Rodhie, S. 2006. Pemanfaatan Zeolit Sebagai Alternatif Pengolahan Limbah Industri. Hal 1-8

Setyo purwoto,2007.penyediaan air minum. Surabaya.

SNI-06-6989.12-2004 Tentang Pengujian Kesadahan.

Sugiyono, 2007. Statistika untuk penelitian. Alfabeta, Bandung.

Tchobanoglous, Burton FL,1991. Waste water engineering. Mc Graw - Hill Inc.

Zaenal Abidin, 2006. Pengaruh Ketebalan Kombinasi Filter Zeolit dengan Karbon aktif terhadap Penuruna Kesadahan Air Sumur Artesis di Sendangguwo, Tembalang, Kota Semarang. $\quad$ http://digilib.unimus.ac.id/gdl.php?mod=browse\&op=read\&id=itptunimus-gdlzaenalabid-5224\&PHPSESSID=1e67af6fa4bdd962b254ed311c991538. ( 10 juli 2010 ) 